\title{
BRPKM
}

Buletin Riset Psikologi dan Kesehatan Mental

http://e-journal.unair.ac.id/index.php/BRPKM

e-ISSN: 2776-1851

ARTIKEL PENELITIAN

\section{Pengambilan Keputusan Pendidikan dan Karir pada Anak Pertama dengan Orang tua Berpreferensi}

\author{
RIFDAH IMTYAAZ \& RUDI CAHYONO* \\ Fakultas Psikologi Universitas Airlangga
}

\begin{abstract}
ABSTRAK
Pengambilan keputusan karir adalah representasi gabungan dari pemahaman individu atas alternatif karir dan manifestasi atas apa yang ingin dilakukan di masa depan. Langkah pertama yang umum ditempuh adalah mengambil pendidikan yang sejalan dengan karir yang dituju. Namun, tidak semua anak memiliki kebebasan penuh dalam mengambil keputusan karena terhalang pilihan orang tua. Menggunakan metode penelitian kualitatif dan perspektif eksistensialisme, penelitian ini mengungkap proses pengambilan keputusan pendidikan dan karir pada anak pertama dengan orang tua berpreferensi, yaitu yang memiliki pilihan atas keputusan anaknya. Anak pertama dipilih dengan asumsi bahwa proses yang mereka lakukan menjadi pengalaman pertama dalam keluarga. Kedua partisipan mengambil keputusan dengan mempertimbangkan pilihannya sendiri dan preferensi orang tua, tetapi harus membuat keputusan baru sebab menemui boundary situation. Keterlibatan orang tua dan persepsi anak terhadapnya ditemukan berperan dalam proses yang dilakukan, pun preferensi disesuaikan dengan masing-masing anak, bukan semata-mata karena urutan kelahiran.
\end{abstract}

Kata kunci: anak pertama, pengambilan keputusan pendidikan dan karir, preferensi orang tua

\begin{abstract}
Career decision-making is a combined representation of an individual's understanding of career alternatives and the manifestation of what they want to do in the future. The most common first step is by taking education that is in line with the intended career. However, some children are hindered by parental choices. Using qualitative research methods in existentialism perspectives, this study reveals the education and career decision-making process in firstborns with parents who have preferences over their decision. Firstborn was chosen on the assumption that the process they did was the first experience in the family. Both participants made a decision by considering their own choice and their parents' preference, but had to take another decision due to boundary situations. Parental involvement and firstborns' perception were found to play a role in the process, with parental preferences adjusted to the child, not solely based on birth order.
\end{abstract}

Keywords: education and career decision making, first born, parent's preference

Buletin Penelitian Psikologi dan Kesehatan Mental (BRPKM), 2021, Vol.1(2), 1478-1496

*Alamat korespondensi: Fakultas Psikologi Universitas Airlangga, Kampus B Universitas Airlangga Jalan

Airlangga 4-6 Surabaya 60286. Surel: rudi.cahyono@psikologi.unair.ac.id

Naskah ini merupakan naskah dengan akses terbuka dibawah ketentuan the Creative Common Attribution License (CC-BY-4.0) (http://creativecommons.org/licenses/by/4.0), 
sehingga penggunaan, distribusi, reproduksi dalam media apapun atas artikel ini tidak dibatasi, selama sumber aslinya disitir dengan baik.

\section{PENDAHULUAN}

Setiap anak pasti memiliki cita-cita, tetapi tidak semua dari mereka memiliki kebebasan penuh dalam menentukan masa depan. Hasil survei LinkedIn menunjukkan bahwa 53\% anak tidak bekerja sesuai cita-cita, dengan 13\%-nya karena terhalang pilihan orang tua. Penelitian Andriani \& Sadewo (2019) menjelaskan adanya motif berpreferensi dan pemaknaan jurusan pada tingkat sekolah menengah, pun survei HSBC mendapatkan bahwa satu dari dua orang tua di Indonesia memiliki pilihan karir (Susilawati, 2016). Pilihan pendidikan dan karir sebagai bentuk keterlibatan orang tua diharap dapat membawa anak pada keberhasilan di masa depan. Pengolahan informasi yang terjadi selama prosesnya membantu memudahkan anak (Arjanggi, 2017), yang mana orang tua juga berperan dalam menyediakan informasi mengenai dunia kerja, fasilitas yang mendukung proses eksplorasi, menunjukkan aspirasi, juga perencanaan untuk pencapaian pendidikan dan karir anak di masa depan (Bryant dkk., 2006).

Melewati tahap Identity vs Role Diffusion dalam Teori Psikososial Erikson, anak dalam masa remajanya memiliki tuntutan untuk mencapai eksistensinya sendiri, membangun identitas diri, menemukan makna hidup, dan memisahkan diri dari peran otoritas (Maxwell \& Gayle, 2013). Namun, sampai pada tingkat tertentu, jika dalam masa remajanya anak terus menjalani identitas di bawah seperangkat rencana yang diatur oleh orang tua, adanya preferensi pendidikan dan karir sebagai bentuk keterlibatan orang tua mungkin menjadi hambatan anak dalam mencapai otonominya sendiri, ketika self-efficacy dan persepsi terhadap harapan orang tuanya sebagai bentuk preferensi turut berpengaruh dalam proses yang mereka lakukan (Dewi, 2017; Peilouw \& Nursalim, 2013; Prabowo dkk., 2019). Memahami parental expectation sebagai faktornya dapat membantu anak menentukan pilihan atau justru membuat mereka kesulitan, terlebih jika ditemukan adanya ketidakcocokan antara pilihan yang diinginkan anak dan orang tua (Hou \& Leung, 2011).

Mengetahui bagaimana keputusan pendidikan dan karir anak dipengaruhi oleh keluarga, penelitianpenelitian sebelumnya menemukan bahwa pilihan karir turut memiliki hubungan tidak langsung dengan urutan kelahiran melalui kepribadian (Collins, 2006), juga intelegensi dan pencapaian pendidikan (Damian \& Spengler, 2020). Dalam Confluence Model (Zajonc, 2001), anak pertama memiliki intelegensi yang lebih tinggi sehingga mereka memiliki kecenderungan untuk mencapai pendidikan yang lebih baik dan karir yang lebih bergengsi. Karena tidak memiliki kakak, mengacu pada Forer (1976, dalam Laing, 1994), anak pertama secara langsung mendapatkan identitas dari orang tua, yang mana dorongan, ambisi, dan pencapaian tujuan dari mereka sangat mempengaruhi sikap anak salah satunya terhadap pendidikan. Anak pertama juga mendapatkan kesempatan dan resource yang lebih memadai untuk mengembangkan potensi intelektual. Mereka dilihat dengan lebih positif, tetapi menghadapi parental expectation yang lebih tinggi yang dapat mempengaruhi persepsi orang tua dan membuat anak memunculkan perilaku yang diinginkan untuk mewujudkannya (Baskett, 1985 dalam Laing, 1994). Anak pertama juga kerap mendapatkan perlindungan dan campur tangan yang berlebihan (Collins, 2006), sebab mereka dianggap memiliki kemampuan yang tinggi saat masih kanak-kanak dan membuat orang tua ingin menguatkannya (Barclay dkk., 2017). Akan tetapi, ketika keinginan untuk menjadi independen semakin besar, penelitian Wray-Lake dkk. (2010) menemukan bahwa pada umur yang sama saat remaja, anak pertama tidak memiliki otonomi sebesar adiknya. Mereka juga memiliki

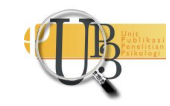


konsepsi yang berbeda atas apa yang dikonsepsikan ibunya terkait otonomi pengambilan keputusan (Campione-Barr dkk., 2015).

Dari hasil penelitian-penelitian sebelumnya yang mendukung ide jika orang tua mampu mengendurkan harapan pada anak berikutnya, anak pertama mungkin merasa kesulitan atas peran dan tanggung jawab yang dilekatkan pada mereka karena lahir lebih awal. Memperkuat hal ini, hasil penelitian Lynn Ng dkk. (2014) juga menemukan bahwa anak pertama lebih peka terhadap perbedaan pola asuh dan perlakuan orang tua terhadap mereka dibandingkan dengan adik-adiknya. Menghadapi situasi yang ditemui karena adanya urutan kelahiran, Miller \& Maruyama (dalam Laing, 1994) menyatakan bahwa anak pertama bisa memiliki standar yang tinggi dan menjadi lebih kritis atas diri mereka sendiri. Diawali dengan kesadaran akan ekspektasi orang tua, hasil penelitian Ogletree menunjukkan bahwa anak pertama juga mengatribusikan pencapaian akademik yang superior dengan kebutuhan untuk lebih sukses di sekolah (Laing, 1994), yang kemudian berlanjut pada penetapan pencapaian karir.

Pada awalnya, minat intrinsik peneliti untuk mencari tahu lebih dalam bagaimana proses pengambilan keputusan pendidikan dan karir pada anak pertama dengan orang tua berpreferensi muncul karena tingginya engagement dari cuitan-cuitan di media sosial yang membicarakan tentang keputusan pendidikan dan karir anak yang dipengaruhi oleh preferensi orang tua, dan secara terpisah, keresahan anak pertama karena konflik peran yang mereka hadapi dalam keluarga. Anak pertama dipilih menjadi konteks penelitian sebab proses yang mereka lakukan akan menjadi pengalaman pertama dalam keluarga. Secara khusus, tujuh dari delapan analisis konsisten pada penelitian Whiteman dkk. (2003) menunjukkan gagasan bahwa orang tua belajar dari pengalaman sebelumnya dan menunjukkan strategi pengasuhan yang lebih efektif pada anak berikutnya, sehingga anak pertama mungkin mendapatkan perlakuan ketika orang tua belum terlatih atau masih mencari cara pengasuhan yang paling tepat. Lantas, peneliti ingin mengangkat bagaimana jika anak pertama dihadapkan pada dua situasi tersebut; Dengan kesadaran atas peran karena adanya urutan kelahiran, anak pertama mungkin menghadapi sikap tertentu dari orang tua yang berpengaruh dalam proses pengambilan keputusan pendidikan dan karirnya.

Dalam upaya mengidentifikasi masalah, ditemukan urgensi dari adanya parental expectation yang lebih tinggi (Laing, 1994) dan didikan orang tua yang lebih ketat pada anak pertama (Hotz \& Pantano, 2015), juga efek dari pola pengasuhan terhadap proses pengambilan keputusan pendidikan dan karir anak (Salim \& Preston, 2019). Apabila pilihan anak pertama dan orang tua bertentangan, kesulitan dalam menghadapi preferensi orang tua bisa berdampak pada kepercayaan diri dan motivasi anak dalam mengejar cita-cita yang diinginkan, diantaranya pengambilan keputusan pendidikan dan karir menjadi terkendala dengan anak yang bingung dalam mengambil keputusan dan cemas untuk berkomitmen, tidak termotivasi, ragu-ragu dengan kemampuan untuk membuat keputusan, dan kesulitan untuk bertanggung jawab pada tugas pemecahan masalah karirnya (Sampson dkk., 2004 dalam Lustig dkk., 2017). Meski begitu, proses pengambilan keputusan pendidikan dan karir ketika orang tua memiliki pilihan terhadap keputusan anak tidak selalu berselisih. Preferensi yang disertai dengan sikap dan peranan lain yang tepat dalam memfasilitasi proses pengambilan keputusan pendidikan dan karir juga bisa membantu anak dalam menentukan pilihannya.

Penelitian ini memiliki pertanyaan utama yaitu bagaimana proses pengambilan keputusan pendidikan dan karir pada anak pertama dengan orang tua berpreferensi, meliputi pengetahuan anak terhadap keinginannya dan keinginan orang tuanya, bagaimana mereka mengambil keputusan dengan dihadapkan pada preferensi orang tua, lalu sikap dan perasaan dalam menjalani keputusan pendidikan dan karir yang diambil. Melalui penelitian kualitatif dan menggunakan perspektif eksistensialisme, 
penelitian ini diharapkan dapat mengungkap aspek-aspek yang lebih luas terkait proses yang anak pertama lakukan dan penerimaan mereka terhadap keputusan yang diambil.

\section{Anak Pertama dan Orang tua Berpreferensi}

Anak pertama atau sulung adalah anak yang paling tua, atau yang lahir pertama dalam suatu keluarga, atau anak tunggal yang beralih posisi karena lahirnya anak kedua (Hadibroto dkk., 2002). Alfred Adler membahas adanya posisi ordinal, yaitu bagaimana anak pertama memaknai peran dalam keluarga karena adanya urutan kelahiran (Armitage, 2007). Posisi ordinal dan urutan kelahiran tidak sepenuhnya menentukan karakteristik seseorang (Adlerian.us, n.d.), tetapi karakteristik yang dimiliki dan situasi yang dihadapi anak pertama dapat berpengaruh pada pengambilan keputusan pendidikan dan karirnya.

Five Factor Model of Personality dalam Sulloway (1999) secara umum menunjukkan kalau anak pertama lebih teliti, dengan perbedaan yang ditunjukkan dengan lebih bertanggung jawab, terorganisir, dan sukses secara akademik. Anak pertama tidak mudah setuju, tetapi lebih terbuka pada pengalaman yang mencerminkan intelektualitas, lebih neurotis ke arah temperamen dan cemas terhadap statusnya, tapi juga lebih extraverted atau terbuka dalam artian asertif dan dominan. Mereka kerap bertindak sebagai orang tua pengganti terhadap adik-adiknya, sebabnya cenderung parent-identified, teliti, dan menghormati otoritas. Hasil penelitian Barclay dkk. (2017) menjelaskan adanya keterkaitan antara aspirasi pendidikan anak pertama yang lebih besar dan kecenderungan mereka untuk mendaftar pada pilihan jurusan perguruan tinggi dengan pendapatan yang lebih tinggi dan mengarah pada karir profesional sebagai pilihan pertama, sebab mereka mungkin melebih-lebihkan kemampuannya sendiri atau kemampuannya dilebih-lebihkan oleh orang tuanya. Kesadaran akan situasi yang dihadapi dapat membuat anak pertama menemui konflik peran, juga karena proses pengambilan keputusan pendidikan dan karir yang mereka lakukan akan diamati dan dijadikan pembelajaran oleh orang tua dan adiknya.

Dalam kamus Cambridge (n.d.), 'orang tua' atau 'parent' adalah orang yang melahirkan untuk dan/atau membesarkan anak. Bersamaan dengan peranan yang dijalani, orang tua mungkin memiliki preferensi atas bagaimana anak akan menjalani hidupnya. Dalam KBBI (n.d.), 'preferensi' berarti (1) hak untuk didahulukan dan diutamakan daripada yang lain; prioritas; (2) pilihan; kecenderungan; kesukaan. Istilah 'Orang tua Berpreferensi' kemudian digunakan untuk menjelaskan orang tua yang diketahui anak memiliki pilihan atas keputusan yang akan mereka ambil. Jika dibahas dari segi pengasuhan, preferensi bisa menjadi bentuk dari pola dan praktek pengasuhan, harapan dan aspirasi, juga sikap orang tua dalam mengasuh anak. Mengacu pada Handbook of Parenting Volume I (Steinberg \& Silk, 2002), parenting styles adalah keseluruhan iklim emosional dari hubungan orang tua dan anak, yaitu semacam konteks afektif yang diekspresikan dan menentukan interaksi keduanya dan secara terpisah, parental practices adalah upaya spesifik yang diarahkan orang tua untuk mensosialisasikan anak dengan cara tertentu. Sementara itu, parental expectations secara umum dijelaskan sebagai keyakinan dan penilaian orang tua terhadap pencapaian anak di masa depan (Ma dkk., 2018). Pilihan pendidikan dan karir yang diinginkan orang tua juga merupakan bentuk harapan yang kontras dengan aspirasi, yaitu keinginan yang secara realistis diharapkan untuk dicapai oleh anak (Seginer, 1983, dalam Yamamoto \& Holloway, 2010).

Tipologi Baumrind (1967, dalam Hoff dkk., 2002) membagi tiga tipe fungsi kontrol yang digunakan orang tua pada anak, yaitu authoritative, authoritarian, dan permissive, yang kemudian dikonseptualisasikan oleh Maccoby dan Martin dalam dua dimensi, yaitu demandingness/control dan responsiveness/warmth. Dalam pengambilan keputusan pendidikan dan karir anak, yang termasuk

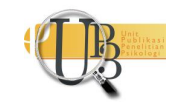


dalam orang tua berpreferensi adalah orang tua dengan pola pengasuhan Authoritative dan Authoritarian yang dicirikan dengan tingginya dimensi demandingness/control. Orang tua bisa memiliki pilihan, menyesuaikan pilihannya dengan minat dan bakat anak, mengarahkan atau bahkan mengharuskan anak untuk mengambil pilihan yang lebih disukai, atau menunjukkan kontrol mereka dalam bentuk lain. Sikap orang tua relatif konsisten, tetapi mungkin berubah karena dampak dari perilaku anak juga hubungan antara mereka dan anak.

\section{Pengambilan Keputusan Pendidikan dan Karir}

Pengambilan keputusan adalah proses berpikir individu dengan mengevaluasi dan mengambil pilihan dari alternatif yang ada (Santrock, 2019). Dalam pengambilan keputusan pendidikan dan karir, anak lebih dulu membangun pengetahuan diri terhadap karir atau yang dinamakan identitas vokasional. Menurut Porfeli \& Lee (2012), tugas perkembangannya meliputi mengeksplorasi pilihan, membuat komitmen, dan memikirkan kembali pilihannya. Baiknya prosesnya dimulai sejak dini agar anak memiliki masa eksplorasi diri yang lebih panjang, terutama saat remaja. Sebab, anak berada dalam masa psychosocial moratorium yang memungkinkan untuk mencoba banyak peran dan mengumpulkan kesempatan tanpa terikat komitmen. Adanya sosialisasi dengan peran dapat membantu mereka mengembangkan tanggung jawab atas pilihannya (Côté \& Levine, 1988).

Pengambilan keputusan pendidikan bisa menjadi langkah awal dari pengambilan keputusan karir dengan memfokuskan minat dan ilmu yang dipelajari, menyalurkan dan mengembangkan potensi, juga menyediakan informasi dan gambaran yang lebih mendalam atas bidang karir yang akan dijalani setelah menyelesaikan studi. Sebagai lanjutannya, pengambilan keputusan karir adalah representasi gabungan dari pemahaman individu atas alternatif karir dan manifestasi atas apa yang ingin dilakukan di masa depan (Zamroni, 2016). Ginzberg (1988) membagi masa perkembangannya dalam 3 tahap: (1) Fantasy (s.d. 11 tahun), dengan anak mulai mengevaluasi minat, (2) Tentative (11-17 tahun), ketika anak mulai mengevaluasi minat, kapasitas diri, dan nilai dari pilihan, dan (3) Reality (17 ke atas), setelah anak mampu menggabungkan faktor personal dan faktor realita dengan berkompromi terhadap kesempatan dan limitasi dalam lingkungan. Ini adalah proses seumur hidup, sehingga individu akan secara konsisten mencari dan mengevaluasi pilihan sampai menemukan kecocokan yang optimal antara tujuan karir dan realita. Prosesnya melibatkan pembuatan dan pelaksanaan komitmen yang membutuhkan pengetahuan dan pola pikir progresif terhadap keputusan karir (Brown, 2002 dalam Zamroni, 2016).

Yazici \& Yazici (2010) menyebutkan bahwa minat terhadap jurusan, jaminan mendapatkan pekerjaan, dan ekspektasi penghasilan yang akan diterima setelah lulus, reputasi dan lokasi institusi, biaya pendidikan, dan status sosial-ekonomi mampu menjadi faktor pengambilan keputusan pendidikan. Selebihnya, keputusan dipengaruhi oleh kecocokan individu terhadap pilihan yang diminati, karakteristik pekerjaan yang berhubungan, keuntungan dari segi psikososial, dan sumber informasi (Nugrahini, 2018). Namun, tidak hanya individu itu sendiri, lingkungan sekitar juga berperan dalam pemilihan jenis pendidikan (Edmonds, 2012). Adapun pada keputusan karir, faktor internal meliputi nilai-nilai kehidupan, intelegensi, minat dan bakat, sifat dan kepribadian, pengetahuan terkait karir dan dirinya sendiri, juga kondisi fisik (Dewi, 2017), lainnya adalah self-efficacy (Dewi, 2017; Peilouw \& Nursalim, 2013; Sari, 2015), juga pengetahuan dan kesadaran atas diri, minat, dan tujuan karir (Istifarani, 2016). Sementara itu, faktor eksternal di luar diri individu meliputi lingkungan sosialbudaya, keadaan dan status sosial-ekonomi, pengaruh keluarga dan orang tua, pendidikan di sekolah, dan lingkungan pergaulan. 


\section{Permasalahan dalam Proses Pengambilan Keputusan}

Menurut John Holland, pilihan karir adalah perluasan kepribadian anak (dalam Zamroni, 2016), tetapi keputusan yang mereka ambil akan dipengaruhi oleh lingkungan, seperti bagaimana orang tua akan memasukkan keinginan, harapan, dan pandangannya pada pilihan anak (Istifarani, 2016). Paparan keluarga mungkin mempengaruhi identitas vokasional anak sebab orang tua akan menjadi pihak pertama yang dicari untuk dimintai saran dan bimbingan mengenai pilihan pendidikan dan karir (Rogers dkk., 2018). Namun, penelitian Kerr dan Stattin (2000, dalam Lundberg dkk., 2009) mendapatkan bahwa pengetahuan orang tua tentang anak lebih sering disebabkan oleh pengungkapan spontan daripada penyelidikan mendalam. Adapun hasil penelitian Istifarani (2016) menemukan minimnya fasilitas dan diskusi sebagai masalah yang dialami sebagian besar siswa, dengan orang tua sebagai penentu karir hanya berperan sebagai motivator dan fasilitator yang seluruhnya tidak menyediakan informasi karir dan sebagiannya juga tidak difasilitasi dengan dukungan emosi.

\section{Desain Penelitian}

\section{METODE}

Penulis menggunakan metode penelitian kualitatif yang menghasilkan data deskriptif berupa kalimat tertulis atau lisan dari individu, juga perilaku yang dapat diamati (Newman, 1999). Pendekatan yang digunakan adalah studi kasus intrinsik, yang menurut Stake (1995 dalam Baxter \& Jack, 2015) dapat memenuhi minat pribadi peneliti untuk memahami konstruk penelitian dengan lebih baik, bukan untuk membangun teori. Kajian kemudian dibatasi pada keseluruhan proses pengambilan keputusan pendidikan dan karir pada anak pertama dengan orang tua berpreferensi, meliputi pengetahuan mengenai pilihan yang diinginkan, tahapan dalam proses yang dijalani, juga sikap partisipan terhadap keputusan yang diambil.

\section{Partisipan}

Partisipan penelitian ini memiliki kriteria: (a) Anak pertama dalam keluarga berusia 17 tahun ke atas, (b) Orang tuanya memiliki preferensi pendidikan dan karir. Pemilihan kriteria (a) didasarkan pada tahap Realistic dari teori karir Ginzberg, yang mana setelah umur 17 tahun atau saat menentukan pilihan yang akan diambil setelah lulus sekolah, anak mulai berpindah dari pilihan karir yang kurang subjektif menuju realistis dan mampu mengevaluasi pilihan sebelum mengambil keputusan. Pemilihan kriteria (b) didasarkan pada pola pengasuhan Authoritative dan Authoritarian. Dua pola pengasuhan ini diidentifikasi dengan tingginya demandingness/control yang memungkinkan orang tua untuk memiliki sikap tertentu agar anak mempertimbangkan pilihan pendidikan dan karir yang lebih disukai.

Pencarian partisipan dilakukan dengan link Google Form yang disebar di media sosial. Peneliti menghubungi responden yang sesuai dengan kriteria, yang bersedia diwawancara sebagai partisipan penelitian, dan yang bersedia orang tuanya juga diwawancara sebagai significant other untuk menambah data dan memantapkan kredibilitas penelitian. Dalam formulir, responden diminta untuk menyertakan highlight proses pengambilan keputusan demi memudahkan seleksi partisipan sesuai dengan kebutuhan penelitian, juga agar peneliti bisa mengidentifikasi preferensi yang dimiliki orang tua dan menyediakan data yang berbeda. Dari dua puluh respon yang masuk, lima responden tidak bersedia diwawancara dan delapan responden tidak bersedia orang tuanya juga ikut diwawancara. Dalam penelitian ini, peneliti menghubungi dua anak pertama sebagai partisipan. Sosok ayah lebih berperan 
dalam proses keduanya, tetapi dikarenakan keterbatasan waktu luang, pengambilan data dilakukan bersama ibu sebagai significant others dari anak pertama dan suaminya.

\section{Teknik Pengumpulan Data}

Dikarenakan kondisi COVID-19, ada pengambilan data wawancara yang dilakukan secara daring melalui Google Meet dan WhatsApp, tapi ada juga yang dilakukan tatap muka atas izin partisipan. Wawancara dilakukan semi terstruktur mengikuti panduan wawancara yang disusun sesuai pertanyaan penelitian dan observasi. Wawancara lebih dulu dilakukan dengan partisipan anak pertama, kemudian secara terpisah dilanjutkan dengan wawancara bersama orang tua untuk mengkonfirmasi data dan mendapatkan data baru, yang akan dikonfirmasi kembali oleh anak pertama di sesi wawancara berikutnya. Sebelum wawancara dimulai, seluruh partisipan sudah menyetujui informed consent dan mengizinkan peneliti untuk merekam proses untuk memudahkan pengolahan data. Peneliti juga meminta bukti fisik yang berkaitan dengan proses pengambilan keputusan jika ada.

\section{Analisis Data}

Penelitian ini menggunakan metode analisis data Miles dan Huberman (1994). Dalam kerangka kerja yang dikembangkan, tiga fase utama analisis data yaitu: (1) Data Reduction atau pemilihan, pemfokusan, penyederhanaan, pengabstrakan, dan transformasi data yang muncul dalam catatan lapangan atau transkripsi, (2) Data Display atau penyajian data yang sudah direduksi, lalu (3) Conclusion Drawing and Verification atau interpretasi data dan menarik kesimpulan. Ketiga fase tersebut bisa dilakukan bersamaan, berulang-ulang, dengan interaktif secara terus menerus sampai datanya jenuh (Miles \& Huberman, 1994). Setelah analisis data tersusun, dilakukan member check pada partisipan untuk memastikan bahwa hasil penelitian ini valid sebelum dipublikasikan.

\section{HASIL PENELITIAN}

\section{A. Partisipan \#1 NFM}

NFM adalah seorang mahasiswi tingkat akhir di Fakultas Kesehatan Masyarakat yang setelah lulus SMA mengejar Fakultas Kedokteran. Menjadi dokter adalah cita-citanya sejak kecil. Minatnya tumbuh karena biasa berdiskusi dan berinteraksi dengan bidang yang dilakoni keluarga. Sebelumnya NFM sempat diarahkan pada Teknik Sipil yang disesuaikan dengan minat dan potensinya, tetapi tidak diteruskan karena setelah mendapat informasi, ia merasa jurusan itu tidak cocok dengan dirinya. Akan tetapi, ia memiliki pandangan yang positif terhadap preferensi orang tua. Dengan keinginan untuk membuat mereka bahagia dan kesadaran bahwa pilihannya sangat terbatas, NFM bersedia menjadikan pilihan orang tua sebagai pilihan kedua tanpa mengantongi cukup informasi karena yakin akan diterima di Kedokteran. Institusi dipilih dengan mempertimbangkan syarat dari orang tua dan opsi yang memungkinkan untuk lolos. Namun, NFM harus menerima bahwa ia justru diterima di FKM yang merupakan pilihan sang ayah. Alhasil, FM sempat kesulitan untuk menerima dan menutup diri, tetapi orang tua terus meyakinkan hingga ia memutuskan untuk mengambil kesempatan dan menolak tawaran Kedokteran swasta sebab memikirkan kedua adiknya yang belum kuliah. NFM berusaha menerima keberadaannya di FKM dan membuka diri pada lingkungan baru, juga mencari nilai tambah untuk dirinya sendiri. Kesulitan akademik yang ditemui diatasi dengan kesadaran untuk bertanggung jawab pada keputusan sembari mempersiapkan diri untuk mengikuti seleksi kedokteran. Sampai kesempatannya habis, NFM melepas cita-citanya dan memilih untuk fokus dengan apa yang ia jalani.

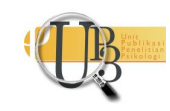


Setelah melewati proses pengambilan keputusannya sendiri sendiri, NFM menyadari bahwa orang tuanya bersikap lebih telaten dengan pengertian bahwa dirinya butuh waktu dan usaha yang lebih banyak untuk meyakinkan diri terhadap pilihan, berbeda dengan adiknya yang cenderung santai. Sebagai anak pertama, ia tidak diberikan tuntutan untuk menjadi yang terbaik, tetapi memiliki ambisi untuk menjadi contoh yang baik bagi adik-adiknya. Pada pemilihan peminatan jurusan, ia diberikan kepercayaan untuk mengambil keputusannya sendiri dengan menyeleksi pilihan yang disesuaikan dengan kapasitas diri. Sebab mendapatkan hasil belajar yang baik, ia bisa mengambil peminatan yang diinginkan. Ia pun lebih yakin dengan keputusannya sendiri dan bisa ikut beropini dalam pengambilan keputusan pendidikan dan karir adiknya. Usai didiskusikan dengan orang tua, ia berencana untuk melanjutkan studi, tetapi belum bisa menentukan pilihan bidang karena minatnya meluas. Institusi karir yang diinginkan masih bertentangan dengan pilihan ayahnya karena pertimbangan gender. Kedepannya, ia berharap untuk menjadi lebih yakin dengan dirinya dan kemampuannya, tetapi tetap ingin mempertimbangan preferensi orang tua dan membuka diri pada lebih banyak kesempatan. NFM mengaku bahwa keputusannya untuk menjalani pendidikan di FKM sudah tepat dan preferensi sebagai bentuk peranan orang tua membantu proses pengambilan keputusan pendidikan dan karirnya.

\section{B. Partisipan \#2 KRM}

Sejak kecil, KRM selalu menjawab ingin menjadi seperti ayahnya yang bekerja di bidang IT. Sebab tidak bisa menghabiskan waktu bersama, ia ingin menekuni bidang yang sama dan menjadi lebih baik dari beliau. Ambisi itu tidak disertai dengan pertimbangan mendalam yang baru dipikirkan setelah masuk SMA. Saat itu, ia adalah siswa unggulan di jurusan IPA, tetapi ingin pindah ke jurusan IPS karena dirasa lebih mudah, cocok dengan gaya belajarnya, dan lingkungannya menyenangkan, tetapi dilarang orang tua dan diarahkan pada jurusan yang mereka percaya juga pertimbangkan dari pandangan pakar mampu mengoptimalkan potensinya, yaitu Teknik Informatika dan Kedokteran. Proses diskusinya berujung konflik dan membuat KRM berhenti mengejar keinginannya di bidang desain. Sebab ditampar, ia merasa takut dan berhati-hati sebelum mengemukakan pendapat. KRM merasa, ada ketidaksesuaian ketika ia diizinkan berdebat, tetapi pada akhirnya tetap akan diarahkan pada preferensi orang tuanya. Sebab pengalaman yang ia dapatkan selama belajar di SMA, ia merasa percaya diri pada bidang IT dan hanya menginginkan jurusan Teknik Informatika. Menganggap itu adalah pilihan orang tuanya, ia merasa harus mendapatkan pendidikan yang terbaik, yaitu ITB dan UGM. Namun, konflik, penolakan, dan keterbatasan pilihan membuatnya semakin pasrah hingga akhirnya bersedia menjadikan Kedokteran sebagai opsi sekalipun menyadari dirinya tidak bisa menoleransi hal-hal berbau medis. Alhasil, ia sempat memanipulasi hasil tes agar tidak lulus pada pilihan yang tidak diinginkan. Pada dua kesempatan terakhir, KRM membiarkan ayahnya memilihkan jurusan dan atas pertimbangan institusi, meski diterima di pilihan yang diinginkan, KRM mengikuti arahan orang tua untuk menjalani perkuliahan di Statistika yang juga bukan pilihannya sendiri.

Menjalani tahun pertama, rasa tidak nyaman karena faktor lingkungan membuatnya sulit untuk bertanggung jawab pada keputusan. Ia tidak memiliki motivasi belajar walau tidak menemui kesulitan akademik. Sebab umurnya lebih muda satu tahun, KRM memanfaatkan kesempatan mengulang seleksi untuk mengejar cita-cita lamanya sebagai pilihan yang paling baik dan diterima. Di Teknik Informatika, ia menemui kesulitan akademik, tapi lingkungan yang mendukung membantunya untuk lebih bertanggung jawab, juga karena kesadaran bahwa ini merupakan pilihannya sendiri. Dalam prosesnya, ada banyak peran dari figur ayah yang menekuni bidang yang sama dalam bentuk arahan dan saran, tetapi KRM juga memiliki pertimbangannya sendiri diantaranya fasilitas, beban belajar, dan keberadaan teman sebagai support system. Pada akhirnya, ia memutuskan untuk mengambil peminatan yang 
disarankan ayahnya dan sekalipun kesulitan, tetap dilanjutkan sampai bekerja. KRM sudah merelakan keinginannya di bidang desain dan saat ini merasa lebih percaya diri pada bidang fokusnya sejak kuliah. Ia dan orang tua sejalan untuk melanjutkan S2, tetapi masih menunggu waktu dan belum sepakat pada pilihan negara. Dari proses pengambilan keputusan yang dilakukan, ia ingin menjadi lebih tegas dalam memperjuangkan keinginannya sendiri. Sesulit apapun, ia yakin ia mampu asal lingkungan mendukung dirinya dalam menjalani proses belajar dan berkarir.

\section{Pilihan yang Diinginkan}

Kedua partisipan memiliki pilihan pendidikan dan karirnya sendiri sejak SD. Dalam teori pengembangan karir Ginzberg (1988), selama tahap Fantasy, anak merefleksikan peran tanpa kesadaran akan realita. Pada partisipan NFM, bayangannya sebatas dengan menjadi dokter, ia bisa membantu orang lain. Pada partisipan KRM, karena melihat ayahnya bekerja, ia ingin menjadi seperti beliau tanpa bayangan akan tanggung jawab atas bidangnya. Beranjak SMA, anak masuk pada tahap Tentative, yang mana kedua partisipan mendapatkan lebih banyak informasi, menemukan minat baru, juga memiliki pemahaman yang lebih baik atas kapasitas diri terhadap pilihan yang diinginkan. Partisipan NFM menerima arahan orang tuanya ke Teknik Sipil sebab berhasil menumbuhkan minatnya sendiri, meski akhirnya kembali ke Kedokteran setelah merasa tidak sesuai dengan dirinya. Partisipan KRM merasa yakin dengan passion-nya di bidang IT karena mampu mengerjakan dan membantu tugas komputer teman-temannya. Sebab tinggal di asrama, sekolah yang menyediakan fasilitas belajar juga berperan dalam pengembangan karir dan identitas vokasional partisipan.

Jurusan dan karir di bidang medis memiliki citra yang baik, sehingga orang tua bisa dengan mudah menyetujui bahkan mendorong anak mengambil pilihan ini. Ketika partisipan NFM mengemukakan keinginannya untuk mengambil Kedokteran, ia mendapat dukungan dan informasi yang membantunya mempertimbangkan pilihan. Pemahaman diri atas motivasi membuat NFM siap menerima konsekuensi. Sementara pada partisipan KRM, meski diharapkan, ia dengan tegas menolak karena menyadari kapasitas diri. Ia mempertimbangkan hal yang bisa membuatnya kesulitan selama menjalani keputusan. Sejalan dengan penemuan Barclay dkk. (2017) bahwa orang tua ingin menguatkan kemampuan anak, partisipan KRM diarahkan ke Teknik Informatika dengan harapan potensinya bisa dioptimalkan dan tidak memberikan izin untuk mengambil jurusan IPS atau bidang desain sebagai pondasi dasar sebab prospeknya dianggap bisa menutup kesempatan KRM pada bidang lainnya. Ini menjelaskan motivasi berpreferensi dan pandangan terhadap jurusan pada orang tua yang juga berasal dengan latar belakang di bidang sains.

Tidak semata-mata karena status sebagai anak pertama, orang tua mengarahkan anak pada preferensi yang disesuaikan dengan minat, potensi, dan karakter. Mendukung hasil penelitian Collins (2006), pengaruh urutan kelahiran terhadap pilihan pendidikan dan karir dimediasi oleh faktor lain. Orang tua partisipan NFM lebih telaten dalam mendampingi karena memahami kecenderungan partisipan saat membuat keputusan, sementara orang tua partisipan KRM bersikap lebih keras dan memasang ekspektasi yang lebih tinggi karena partisipan dianggap lebih mampu secara akademik dan lebih bisa berargumen. Orang tua juga melibatkan pandangan pakar dan menyediakan fasilitas instrumental yang cukup memadai untuk mendukung prosesnya. Lalu, kedua orang tua mengizinkan partisipan berkarir, tapi juga berpesan agar mempertimbangkan gender. Ketika mengasuh anak perempuan, ayah akan memposisikan diri pada posisi anak dalam memilih norma sosial yang harus dipatuhi (Borrell-Porta dkk., 2018), sebabnya kedua partisipan diperingatkan agar tidak bekerja terlalu keras, juga memilih pekerjaan yang lebih aman dan menjamin. 


\section{Keputusan yang Diambil dengan Dihadapkan pada Preferensi Orang tua}

Orang tua berusaha memberikan dukungan emosional, tetapi penerimaan dari kedua partisipan berbeda sebab adanya perbedaan persepsi anak terhadap preferensi orang tua, juga perbedaan sikap orang tua terhadap preferensinya. Menurut Prabowo dkk. (2019), saat remaja, persepsi terhadap harapan orang tua memiliki pengaruh yang lebih besar terhadap pengambilan keputusan pendidikan dibandingkan self-efficacy. Di samping itu, persepsi akan dukungan dari orang tua dapat menimbulkan rasa aman dan percaya diri dalam menghadapi situasi baru dan tantangan (Marliyah dkk., 2004). Partisipan NFM lebih mudah menerima preferensi, pun orang tua percaya dengan pilihan partisipan karena memiliki pandangan yang positif terhadap tujuan masing-masing. Menurut Nurmi, kesadaran akan pengalaman dan pengetahuan yang terbatas membuat anak merasa membutuhkan bimbingan dan dukungan dari orang tua (Rini, 2014). Sementara pada partisipan KRM, ada penolakan terhadap sikap orang tua terutama setelah pilihan yang diinginkan ditentang, disebabkan karena ketimpangan antara harapan orang tua dan bagaimana partisipan ingin menjalani hidupnya. Partisipan juga merasa kesulitan untuk menyesuaikan laju dan gaya belajarnya dengan optimalisasi yang diinginkan orang tua. Konflik seperti ini bisa menyebabkan diskusi tidak terbuka, bergantung pada dinamika hubungan antara anak dan orang tua, juga keinginan anak untuk meraih otonomi (Rogers dkk., 2018).

Kedua partisipan menyadari minat dan pilihan yang terbatas, tetapi kesadaran akan konsep diri dan efikasi diri membantu mereka melalui krisisnya. Partisipan NFM memahami konsekuensi yaitu tidak memiliki pilihan cadangan, tapi berpegang teguh pada ajaran orang tua dan bersikap optimis sampai lolos di Kedokteran. Internalisasi ini adalah hasil dari paparan dan identitas orang tua. Ini juga tampak pada partisipan KRM setelah menjalani pilihannya di Teknik Informatika, tetapi sebelum itu, penolakan dan ingatan yang tidak menyenangkan dengan ayahnya pada pengambilan keputusan sebelumnya membuat ia merasa tidak berdaya. Menurut Roe \& Lunneborg (1990, dalam Brown, 2004), penguatan dan hukuman dalam pengasuhan anak mempengaruhi pilihan kejuruan. Kualitas hubungan yang baik, komunikasi yang terbuka, dukungan dan kepercayaan yang didapat dari orang tua juga mempengaruhi aktivitas eksplorasi, aspirasi vokasional, dukungan masa depan, dan persepsi anak terhadap batas toleransi dalam memilih karir (Paloş \& Drobot, 2010). Keberhasilan anak dalam menginternalisasi model kerja yang positif dapat membantu anak mengeksplorasi pilihan pendidikan dan karir, juga belajar dari pengalaman. Syok karena diterima di pilihan lain setelah fokus pada satu pilihan, pertimbangan partisipan NFM untuk mengambil kesempatan di FKM diantaranya karena institusi yang bagus dan tidak ada jaminan lolos di Kedokteran kalau ia memilih untuk menunda kuliah. Pada situasi yang sama, ketika sudah melalui banyak kegagalan dan sudah mendekati tahun ajaran baru, partisipan KRM juga berharap untuk diterima di mana saja asal bisa segera kuliah. Pengembangan karir bisa menjadi serba salah jika individu gagal mengikuti tuntutan dari budaya dan teman sebaya (Osipow, 1973). Dengan dihadapkan pada keterbatasan situasi, keduanya tidak bisa menjalani keputusan yang diinginkan dan harus mengambil keputusan baru.

Jika dikaitkan dengan delapan strategi pemilihan karir menurut Dinklage (dalam Sharf, 1992, dalam Istifarani, 2016) dan dua ketidakteraturan dalam Action Stage pada pengambilan keputusan karir sebagai Boundary Situation (Cohen, 2003), kedua partisipan sempat mengambil keputusan dengan tidak efektif. Partisipan NFM cenderung intuitif dan impulsif dalam menjadikan preferensi orang tua sebagai pilihan kedua karena tidak disertai dengan pencarian informasi secara mendalam. Setelah gagal dan kesulitan menerima kenyataan, ia mencoba mempertimbangkan saran-saran yang diberikan orang tua sampai akhirnya mau menjalani perkuliahan FKM dengan perencanaan yang lebih matang. Lain dengan partisipan KRM, ia bersikap compliant atau pasif untuk menghindari konflik. Bayangan akan pertengkaran membuatnya lebih berhati-hati. Sementara merasa sudah tidak punya pilihan, KRM tetap mencoba Kedokteran yang dirasa di luar kapasitas dirinya. Kondisi paralytic membuat ia bimbang dan

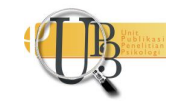


berharap pada pilihan yang tidak diinginkan, juga membiarkan orang tuanya mengambil alih dan menerima apapun pertimbangan mereka. Pada situasi seperti ini, keluarga dapat memastikan dukungan emosional sebab kualitas hubungan keluarga yang baik mampu menahan efek mencekam selama masa transisi anak menjadi dewasa, juga memfasilitasi proses dan aktivitas eksplorasi vokasional (Vignoli dkk., 2005). KRM mengambil keputusan dengan lebih efisien usai merasa tidak bisa lagi menoleransi kesulitan dari faktor lingkungan dan konsekuensi kegagalan dalam mempertanggungjawabkan keputusan sebelumnya.

\section{Perasaan dan Sikap dalam Menjalani Keputusan}

Kedua partisipan dihadapkan pada situasi yang mengharuskan mereka memikirkan kembali pilihannya. Meski ada rasa takut karena ekspektasi orang tua yang tinggi, partisipan KRM memiliki cukup kesadaran atas kesempatan dan kapasitas dirinya sendiri. Ia mengurungkan keinginan untuk mengambil peminatan grafis setelah membandingkan fasilitas dan beban belajar yang sama sulitnya. Untuk faktor eksternal (Osipow, 1973), Roe melihat bahwa bakat ditentukan oleh gen, tapi terpisah dari fungsi genetik dikarenakan pencapaian, juga dipengaruhi oleh hasil kultur dan lingkungan. KRM merasa jika ayahnya tidak bisa, maka ia juga tidak akan bisa. Dengan mengambil peminatan sesuai arahan ayahnya, ia bisa mengharapkan bantuan walau pada kenyataannya tidak banyak dibantu. Proses belajar kemudian juga dimudahkan dengan keberadaan teman-teman dari peminatan yang sama. Mengingat kesulitannya di Statistika, juga salah satu alasannya ingin pindah ke jurusan IPS, pada akhirnya KRM membuat batas toleransi: Asal nyaman dengan lingkungan, ia yakin ia mampu.

Teman dan lingkungan sebagai support system juga mendukung proses partisipan NFM dengan menjadi salah satu alasan untuk bertahan selama berusaha menerima keberadaannya di FKM. Seperti yang dipaparkan Vignoli dkk. (2005), sebab menunjukkan pola kelekatan yang secure dengan orang tua, NFM mampu membawa dirinya mengeksplor lingkungan edukasi dan vokasional. Aluja dkk. (dalam Paloş \& Drobot, 2010) menyatakan bahwa tingkat adaptasi anak terhadap lingkungan dipengaruhi oleh gaya pengasuhan, dengan pengasuhan yang suportif, halus, dan penuh kasih sayang memastikan iklim keluarga yang mendukung proses sosialisasi. Dampaknya, anak memiliki stabilitas emosi, ekstroversi, sosiabilitas, dan empati yang lebih tinggi. Adapun sebagai hasil dari pola pengasuhan autoritatif, orang tua mendambakan kedewasaan dan mendukung otonomi sehingga anak mampu membawa diri mereka mengeksplor lingkungan dan membantu proses pengambilan keputusan pendidikan dan karirnya (Salim \& Preston, 2019). Dengan begitu, ia tidak ingin membatasi diri dan ingin jadi lebih yakin dengan dirinya atas keputusan yang akan diambil.

Sejalan dengan hasil penelitian Vignoli dkk. (2005), sebagai perempuan, kedua partisipan memiliki ketakutan akan kegagalan. Partisipan NFM memastikan dirinya tidak tertinggal dan mendapatkan hasil terbaik sebagai pemanfaatan yang maksimal dari kesempatan mengemban pendidikan. Partisipan KRM juga meminta bantuan teman dan memposisikan diri untuk mau belajar lewat mengerjakan tugas, sekalipun ada faktor lain yaitu ketakutan nilainya akan dipermasalahkan ayahnya. Kesadaran akan kompetensi yang diperlukan dalam bidang pilihan juga berperan dalam menentukan kesiapan partisipan. Dari penelitian yang sama, perempuan ditemukan akan mengeksplor lebih jauh pilihan yang dianggap lebih mungkin dan/atau lebih dekat dengan level kemampuan yang diyakini. Partisipan NFM memilih peminatan dengan menyeleksi bidang-bidang yang tidak ia kuasai, sementara partisipan KRM, setelah lulus kuliah dan mendapat izin mencoba bidang desain, ia memilih mundur karena merasa lebih siap pada bidang yang sudah ditekuni sejak awal. 
Sampai pada tahap reality, individu akan mengintegrasi kesukaan dan ketidaksukaan dengan kemampuan, lalu menggabungkan keduanya dengan nilai sosial dan personal. Sebab salah satu sifat dari proses kristalisasi pilihan adalah irreversible, langkah menuju tujuan karir akan terus berlanjut, mulai dari pengambilan keputusan pendidikan sebelumnya dan memperkecil kesempatan individu untuk mengubah arah. Individu juga perlu berkompromi, sebab akan dicari pilihan yang optimal diantara keinginan, kemampuan, dan realita dunia kerja (Ginzberg, 1988). Setelah mengambil dan menjalani keputusan, kedua partisipan memilih untuk melepas cita-citanya. Terlebih pada partisipan KRM, setelah meneruskan keputusan pendidikannya, sudah dibuat komitmen dan spesifikasi. Sebab pengambilan keputusan pendidikan dan karir adalah proses seumur hidup, individu akan kembali menjumpai proses ini di tahapan kehidupan selanjutnya dan kedua partisipan sudah memiliki bayangan atas sikap yang ingin mereka tunjukkan jika kembali dihadapkan dengan preferensi orang tua sebagai hasil evaluasi dari proses yang sudah dilakukan.

\section{DISKUSI}

Dalam hidup, individu akan menghadapi kekhawatiran utama yang berasal dari masalah yang tak terhindari atau Boundary Situations (Yalom, 1980). Ini adalah pengalaman mendesak atau peristiwa penting yang mengubah hidup, seperti bagaimana partisipan harus mengambil keputusan baru setelah dihadapkan dengan kenyataan yang tidak menyenangkan: kegagalan dan penolakan. Keadaan ini membuat individu sadar akan tema-tema eksistensial diantaranya kebebasan (freedom), tanggung jawab (responsibility), ketidakbermaknaan (meaninglessness), dan keaslian (authenticity). Kierkegaard (dalam Corey, 2009) menyebutkan adanya peran kecemasan dan ketidakpastian, sehingga keputusan baru membentuk diri individu yang baru. Kesadaran anak atas preferensi orang tua dan persepsi mereka sendiri atas proses yang dihadapi dapat menjadi sumber kecemasan. Pada partisipan KRM, preferensi orang tua yang bertentangan dengan pilihan anak, juga bentuk dan pemaknaan anak atas sikap yang negatif berdampak pada motivasi dalam mempertahankan cita-cita. Meski preferensi ditujukan untuk mengoptimalkan potensi yang diyakini orang tua, kesulitan anak dalam menyikapi praktek pengasuhan authoritarian yang diterapkan menyinggung tema-tema eksistensial dalam diri. Menurut Maisel (2018), luka karena adanya keterbatasan yang disebabkan oleh otoritas orang tua mampu membuat anak tumbuh dengan ketidakpercayaan bahwa minat dan usahanya berarti. Perasaan seperti ini dapat membawa individu pada kesedihan, kecemasan, keputusasaan, memiliki self-image yang buruk, juga kegagalan dalam mewujudkan tujuan hidup. Menurut partisipan, memperjuangkan keinginannya di bidang desain hanya akan berakhir percuma, sebab pada akhirnya ia akan diarahkan kembali pada pilihan yang diharapkan orang tua padanya.

Tidak hanya peran kecemasan, Yalom (1980) bersugesti bahwa dalam membuat keputusan, individu memiliki kesadaran akan kebebasan dan tanggung jawab. Adapun menurut Harren, kesadaran akan tujuan meliputi pengetahuan individu atas dunia yang akan dihadapi dan potensi mereka dalam keputusan yang ingin diambil (Cohen, 2003). Partisipan NFM menjaga optimisme dalam mengejar jurusan Kedokteran sebagai pilihan satu-satunya sebab ia memiliki tujuan yang jelas dan berjangka panjang. Sebagai anak pertama, ia memiliki ambisi untuk mencapai kesuksesan bagi dirinya sendiri juga menjadi contoh yang baik untuk adik-adiknya. Akan tetapi, kesadaran akan keterbatasan finansial membuatnya mengesampingkan kebebasan dalam mengambil universitas swasta agar biayanya bisa dialokasikan untuk pendidikan adik-adiknya di masa mendatang dan kehilangan salah satu kesempatan untuk mengejar cita-cita. Walaupun hipotesis Resource Dilution dari Blake (1881, dalam Barclay dkk., 2017) menyatakan bahwa anak pertama memiliki keuntungan salah satunya atas ketersediaan finansial, juga temuan yang bertentangan atas adanya kecenderungan orang tua untuk membagi sumber

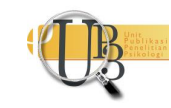


daya secara adil bagi setiap anak (Hertwig dkk., 2002, dalam Lynn Ng dkk., 2014), kekhawatiran bahwa mereka akan menguras sumber keuangan keluarganya bisa menambah keterbatasan anak pertama dalam menentukan langkah untuk mencapai tujuannya sendiri.

Ketika dihadapkan pada Bounded Rationality, mekanisme pertahanan yang digunakan individu dalam meredakan kecemasan diantaranya mendistorsi dan menyangkal kenyataan dengan menggunakan keyakinan yang kaku, salah, dan irasional (Yalom, 1980). Pemaksimalan pengambilan keputusan dilakukan dengan memilih pilihan alternatif yang memenuhi kriteria minimal (Milburn \& Billings, 1976), seperti bagaimana kedua partisipan mengambil kesempatan untuk kuliah di tahun itu meski bukan di pilihan yang diinginkan, seperti bagaimana kedua partisipan mengambil kesempatan untuk kuliah di tahun itu meski bukan pada pilihan yang diinginkan. Menurut Osipow (1973), pengembangan karir bisa menjadi serba salah jika individu gagal mengikuti tuntutan budaya dan teman sebaya. Kepastian akan penerimaan menjadi pilihan yang lebih baik dibanding tidak sama sekali, walau pada akhirnya mereka sempat menemui kesulitan dalam menjalani juga mencari makna dari keputusan yang diambil. Saat menemui kesulitan dalam pilihan yang diambil, Frankl (dalam Cohen, 2003) menjelaskan existential vacuum sebagai masa individu merasa tidak bermakna lewat rasa frustasi, kehampaan, depresi, kebosanan, dan apatisme karena tidak adanya tujuan, sementara makna yang sebenarnya mencakup transendensi diri dan komitmen dan akan membawa individu pada evaluasi ulang. Sementara itu, Yalom (1980) menjelaskan existential guilt, yaitu ketika kecemasan dan penyesalan diasosiasikan dengan kegagalan individu dalam mencapai potensi diri. Menurut Heidegger, kesadaran akan existential guilt bisa menjadi dorongan yang positif dan konstruktif (Cohen, 2003), sebab individu akan menemukan kebutuhan untuk hidup dengan lebih baik. Ini menggambarkan situasi partisipan KRM saat kuliah di Statistika dan bagaimana ia membuat batas toleransi, juga bagaimana kesulitan yang ditemui partisipan NFM dalam menumbuhkan minat di bidang Farmasi dijadikan dipertimbangkan sebelum menemui kendala yang lebih serius ketika menjalaninya nanti.

Dalam Hermawan (2021), May meyakini konsep diri adalah syarat dasar dari eksistensi manusia, sehingga pemahaman yang baik akan diri masing-masing akan memudahkan individu mengetahui tindakannya. Kehampaan menjadi kondisi yang dihadapi individu ketika kenyataan tidak sesuai dengan harapan. Jika diikuti dengan kesepian, situasinya bisa diantisipasi dengan mencari kesibukan dan bersosialisasi. Pada partisipan NFM, ia tidak ingin kesulitannya dalam menerima membawa dampak buruk pada banyak hal. Penelitian ini berhasil mengungkap bagaimana partisipan berhasil membuat dirinya tidak merasakan kehampaan dan kecemasan, dengan memanfaatkan kesadaran akan kesempatan yang sebelumnya tidak dimiliki saat masih tinggal bersama orang tua dengan mencari kesibukan sebagai nilai tambah agar untuk dirinya sendiri. Ia juga membangun keberanian sosial untuk melibatkan diri dengan orang lain. Integrasi sosial sebagai usaha dalam menemukan kembali kesadaran diri membawa individu pada refleksi atas kebutuhan untuk hidup bersama individu lain tanpa kehilangan identitas sebagai pribadi yang eksis (May, 2019, dalam Hermawan, 2021). Alhasil, NFM merasa terbantu selama proses adaptasi, juga menjadi dirinya yang baru dan lebih baik dari yang di SMA. Keterbukaan juga membuka jalannya pada pilihan-pilihan baru; Dari yang tadinya merasa pilihannya sangat terbatas, kini ia belum bisa menentukan fokus untuk keputusan lanjutnya sebab bidang minatnya meluas dan ada tujuan untuk mengambil pilihan yang paling baik.

Kepuasan karir dan stabilitas dapat diraih dengan adanya korespondensi yang tinggi antara pilihan dan kemampuan individu dalam menemukan nilai dan kesempatan. Lantas, kegagalan dapat membawa mereka pada ketidakpuasan dan instabilitas yang memungkinkan individu mengulang ronde baru dari proses pengambilan keputusan (Cohen, 2003). Sartre (1971, dalam Corey, 2009) juga meyakini bahwa kegagalan mencapai kebebasan dan pilihan dapat menyebabkan masalah emosional yang bisa berujung 
pada ketidaksediaan untuk menerima tanggung jawab pribadi. Saat SMA, kecemasan sebab tanggung jawab sebagai siswa jurusan IPA dinilai lebih berat dibanding siswa jurusan IPS membuat partisipan KRM ingin menghindar dari pilihan yang diberikan padanya. Selama seleksi perguruan tinggi, dalam kondisi helpless, tanpa sadar ia kembali menghindari tanggung jawab dengan membiarkan orang tua mengambilkan keputusan untuknya. Memindahkan tanggung jawab adalah bentuk pertahanan diri melalui distorsi alternatif untuk menghindari kecemasan eksistensial. Nyatanya, rasa takut dan sikap pasrah membuatnya diam di tempat, hingga akhirnya sadar tidak bisa bertanggung jawab pada keputusan yang sudah diambil. Keputusan baru pun dibuat; KRM mengejar Teknik Informatika, kemudian mengambil peminatan Data. Bidang desain tidak lagi dijadikan pilihan meski minatnya masih ada dan ditekuni di kesempatan lain. Ia memilih untuk melanjutkan keputusan yang sudah diambil karena merasa lebih siap. Dalam kesulitan yang dihadapi, ia tetap merasa autentik, menemukan stabilitas, juga lebih banyak kesempatan.

Mengingat proses pengambilan keputusan pendidikan dan karir tidak lepas dari keterlibatan orang tua, menurut May, eksistensi individu juga merupakan hasil dari pola asuh yang baik. Dapat dilihat bagaimana anak tumbuh, menyadari kapasitas, dan bisa mengambil jalan keluar yang tepat saat dihadapkan dengan kecemasan. Anak yang dieksploitasi lewat tuntutan untuk mewujudkan keinginan orang tua justru menjadi tidak bebas, tumbuh dalam keadaan neurotik dan pemberontak, dan terjerat tali pusar psikologis (May, 2019, dalam Hermawan, 2021). Partisipan NFM yang diberikan kepercayaan untuk mengambil keputusan sendiri di bawah pengawasan orang tua berhasil melalui prosesnya dengan baik dan siap membuka diri pada lebih banyak kesempatan. Sementara itu, meski orang tua KRM memiliki tujuan yang sama, praktek otoriter yang diterapkan dari ekspektasi sebagai anak pertama yang lebih mumpuni secara akademik menghalangi kebebasan partisipan dalam mewujudkan otonominya sendiri. Menurut Heiddeger, dalam periode Identity vs Role Diffusion dari teori Psikososial Erikson, penolakan membuat partisipan yang seharusnya menemukan identitas melalui upaya pemisahan diri dari otoritas justru menemui kecemasan sebab keterlemparan membuat individu tidak mengerti apa yang harus dilakukan (Hermawan, 2021). Pada akhirnya, jika dikaitkan dengan konsep absurditas Albert Camus, menjalani keputusan yang tidak diinginkan setelah dihadapkan dengan kecemasan adalah pilihan untuk tetap hidup.

Ketika partisipan mempertimbangkan preferensi dan pertimbangan yang diberikan orang tua, Heidegger (dalam Corey, 2009) menjelaskan adanya phenomenological existentialism. Individu menerjemahkan kebijaksanaan dari perasaan yang samar ke kesadaran eksplisit, sehingga mereka bisa membangun penyelesaian yang lebih baik atas apa yang mereka inginkan. Dari yang tadinya memiliki pandangan sendiri, lalu menganggap pandangan orang tua ada benarnya. Misal pada partisipan KRM, menilik lebih jauh pada identitas dan pengalaman yang dimiliki, keyakinan bahwa dirinya mampu membawanya kembali pada eksistensi. Mendukung pandangan Hardiman (2008, dalam Hermawan, 2021), kefanaan yang melingkupi manusia mendorong mereka memproyeksikan diri menuju masa depan, membuka diri, menafsirkan keberadaannya di dunia, dan menghayati berbagai kemungkinan yang ada. Meski sempat merasa kesulitan, kedua partisipan memilih untuk melupakan pilihan pendidikan dan karirnya dan fokus menjalani pilihan sebagai bentuk tanggung jawab terhadap keputusan yang sudah diambil. Kedepannya, mereka ingin lebih memahami dan memperjuangkan kapasitasnya sendiri untuk melepas ketergantungan yang bisa membuat mereka tak berdaya, termasuk kesadaran atas preferensi orang tuanya.

Penelitian ini berhasil mengungkap pertimbangan anak pertama dalam mengambil keputusan, tetapi kurang mendalam pada bagaimana mereka memaknai peran sebagai anak pertama dan bagaimana mereka memaknai pilihan dan keputusan pendidikan dan karir yang diambil. Agar mendapat sudut 
pandang yang lebih beragam, penelitian mendatang dapat mencari partisipan anak pertama dengan orang tua berpreferensi yang berhasil memperjuangkan keinginannya, yang belum mampu berdamai dengan keputusan, juga yang berjenis kelamin laki-laki. Dikarenakan proses pengambilan keputusan pendidikan dan karir adalah proses seumur hidup, akan lebih baik jika anak pertama terus mengevaluasi minat dan kemampuan sebagai pemahaman atas kapasitas diri, juga kesempatan, situasi, dan kondisi agar dapat mengambil keputusan yang efektif. Orang tua juga bisa menjaga kelekatan yang secure dan komunikasi yang baik agar anak bisa membangun pemikiran positif akan preferensi. Sebagai bagian dari luar keluarga yang juga berperan dalam identitas vokasional dan pengembangan karir anak, sekolah dan guru BK dapat membantu anak menemukan dirinya dengan merangkul keresahan mereka, mengartikulasikan aspirasi karir pribadi, dan menawarkan solusi yang membangun motivasi tanpa terpaku pada gagasan yang ideal.

\section{SIMPULAN}

Kedua partisipan melewati tahapan pengembangan karir untuk mencapai pemahaman atas pilihannya sendiri. Ketika dihadapkan pada preferensi orang tua, partisipan NFM mendapat dukungan, sementara partisipan KRM mendapatkan penolakan dan memilih untuk mengikuti keinginan orang tua demi menghindari konflik. Namun, boundary situations membuat mereka kembali mempertimbangkan pilihan dan mengambil keputusan baru. Dalam upaya menerima, partisipan NFM menunjukkan sikap mau beradaptasi, sementara partisipan KRM mampu menentukan batas dan menyadari bagaimana kenyamanan terhadap lingkungan bisa berpengaruh dalam hidupnya. Atas kesadaran pada pilihan yang diambil, keduanya berusaha bertanggung jawab dengan menjalani keputusan dengan sebaik-baiknya. Poin penting dalam hasil penelitian ini adalah bagaimana sikap orang tua tidak didasarkan semata-mata karena partisipan anak pertama, tetapi disesuaikan dengan kemampuan dan karakteristiknya. Dapat dikatakan pula bahwa keterlibatan orang tua yang tepat, keterbukaan anak pada pilihan, persepsi terhadap sikap dan preferensi orang tua, juga hubungan antara anak dan orang tua yang baik turut menjadi faktor yang memudahkan keseluruhan prosesnya.

\section{UCAPAN TERIMAKASIH}

Terima kasih kepada Bapak Rudi Cahyono yang telah membimbing penelitian sejak bulan Maret 2020, juga seluruh responden, partisipan, juga orang tua yang berkenan untuk membagikan pengalaman pengambilan keputusan pendidikan dan karirnya. Tak lupa untuk Papa dan Mama; Tanpa kebijakan kalian, Kakak tidak akan sampai di sini.

\section{DEKLARASI POTENSI TERJADINYA KONFLIK KEPENTINGAN}

Rifdah Imtyaaz dan Rudi Cahyono tidak bekerja, menjadi konsultan, memiliki saham, atau menerima dana dari perusahaan atau organisasi manapun yang mungkin akan mengambil untung dari diterbitkannya naskah ini.

\section{PUSTAKA ACUAN}

Andriani, P. R. \& Sadewo, F. X. S. (2019). Fenomenologi Orang Tua dalam Memilih Jurusan terhadap Anak di Sekolah (Studi Kasus di SMA Negeri 2 Ponorogo). Jurnal Paradigma, 7(3).

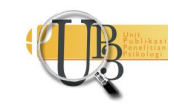


https://ejournal.unesa.ac.id/index.php/paradigma/article/view/29922

Arjanggi, R. (2017). Identifikasi Permasalahan Pengambilan Keputusan Karir Remaja. Psikologika: Jurnal $\begin{array}{lllll}\text { Pemikiran Dan } & \text { Penelitian } & \text { Psikologi, } & \text { 22(2), }\end{array}$ https://doi.org/10.20885/psikologika.vol22.iss2.art3

Armitage, S. (2007). Birth Order: College Student's Perceptions of Their Ordinal Position Compared to Alfred Adler's Categories [Tesis, The Graduate School University of Wisconsin-Stout]. http://digital.library.wisc.edu/1793/42229

Barclay, K., Hällsten, M., \& Myrskylä, M. (2017). Birth order and college major in Sweden. Social Forces, 96(2), 629-660. https://doi.org/10.1093/sf/sox069

Baxter, P., \& Jack, S. (2015). Qualitative Case Study Methodology: Study Design and Implementation for Novice Researchers. The Qualitative Report. https://doi.org/10.46743/2160-3715/2008.1573

Borrell-Porta, M., Costa-font, J., \& Philipp, J. (2018). The 'Mighty Girl’ Effect: Does Parenting Daughters Alter Attitudes towards Gender Roles? Oxford Economic Papers, 71(1), 25-46. https://doi.org/https://doi.org/10.1093/oep/gpy063

Brown, M. T. (2004). The Career Development Influence of Family of Origin: Considerations of Race/Ethnic Group Membership and Class. The Counseling Psychologist, 32(4), 587-595. https://doi.org/10.1177/0011000004266007

Bryant, B. K., Zvonkovic, A. M., \& Reynolds, P. (2006). Parenting in relation to child and adolescent vocational development. Journal of Vocational Behavior, 69(1), 149-175. https://doi.org/10.1016/j.jvb.2006.02.004

Campione-Barr, N., Lindell, A. K., Short, S. D., Greer, K. B., \& Drotar, S. D. (2015). First- and second-born adolescents' decision-making autonomy throughout adolescence. Journal of Adolescence, 45(October), 250-262. https://doi.org/10.1016/j.adolescence.2015.10.009

Cohen, B. N. (2003). Applying existential theory and intervention to career decision-making. Journal of Career Development, 29(3), 195-209. https://doi.org/10.1177\%2F089484530302900306

Collins, C. (2006). The Relationship Between Birth Order and Personality and Career Choices [Providence College]. http://digitalcommons.providence.edu/socialwrk_students/13

Corey, G. (2009). Theory and practice of counseling and psychotherapy (8th ed.). Brooks/Cole.

Côté, J. E., \& Levine, C. (1988). The relationship between ego identity status and Erikson's notions of institutionalized moratoria, value orientation stage, and ego dominance. Journal of Youth and Adolescence, 17(1), 81-99. https://doi.org/10.1007/BF01538725

Damian, R. I., \& Spengler, M. (2020). Negligible effects of birth order on selection into scientific and artistic careers, creativity, and status attainment. European Journal of Personality, 35(6), 775-796. https://doi.org/10.1177/0890207020969010

Dewi, R. P. (2017). Hubungan Efikasi Diri Dengan Pengambilan Keputusan Karir Pada Mahasiswa

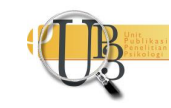


Tingkat Akhir Fakultas Psikologi Universitas Mercu Buana Yogyakarta. Insight: Jurnal Ilmiah Psikologi, 19(2), 87. https://doi.org/10.26486/psikologi.v19i2.601

Edmonds, J. (2012). Factors influencing choice of college major: what really makes a difference? [Disertasi, Rowan University]. https://rdw.rowan.edu/etd/147/

Ginzberg, E. (1988). Toward a Theory of Occupational Choice. The Career Development Quarterly, 36(4), 358-363. https://doi.org/10.1002/j.2161-0045.1988.tb00510.x

Hadibroto, I., Syamsir, A., Suryaputra, E., Femi, O. (2002). Misteri Perilaku Anak Sulung, Tengah, Bungsu, dan Tunggal. Gramedia Pustaka Utama.

Hermawan, U. (2021). Konsep Diri Dalam Eksistensialisme Rollo May. Jaqfi: Jurnal Aqidah Dan Filsafat Islam, 6(1). https://journal.uinsgd.ac.id/index.php/jaqfi/article/view/11669

Hoff, E., Laursen, B., \& Tardif, T. (2002). Socioeconomic Status and Parenting. In M. H. Bornstein (Ed.), Handbook of Parenting Vol. 2: Biology and Ecology of Parenting (pp. 231-252). Lawrence Erlbaum Associates.

Hotz, V. J., \& Pantano, J. (2015). Strategic parenting, birth order, and school performance. Journal of Population Economics, 28(4), 911-936. https://doi.org/10.1007/s00148-015-0542-3

Hou, Z. J., \& Leung, S. A. (2011). Vocational aspirations of Chinese high school students and their parents' expectations. Journal of Vocational Behavior, 79(2), 349-360. https://doi.org/10.1016/j.jvb.2011.05.008

Istifarani, F. (2016). Pengaruh Dukungan Keluarga terhadap Pengambilan Keputusan Karir Siswa Kelas X di SMK Negeri 1 Depok. Jurnal Bimbingan Dan Konseling, 4(5).

Laing, A. S. (1994). Parent perceptions and expectations for siblings of different birth-order positions [Tesis, Iowa State University]. https://lib.dr.iastate.edu/rtd/16743

Lundberg, S., Romich, J. L., \& Tsang, K. P. (2009). Decision-making by children. Review of Economics of the Household, 7(1), 1-30. https://doi.org/10.1007/s11150-008-9045-2

Lustig, D. C., Xu, Y. J., \& Strauser, D. R. (2017). The Influence of Family of Origin Relationships on Career Thoughts. Journal of Career Development, 44(1), 49-61. https://doi.org/10.1177/0894845316633791

Lynn Ng, W., Mofrad, S., \& Uba, I. (2014). Effect of birth order on the differential parental treatment of children. Asian Social Science, 10(14), 132-137. https://doi.org/10.5539/ass.v10n14p132

Ma, Y., Siu, A., \& Tse, W. S. (2018). The Role of High Parental Expectations in Adolescents' Academic Performance and Depression in Hong Kong. February. https://doi.org/10.1177/0192513X18755194

Maisel, E. (2018). Helping Survivors of Authoritarian Parents, Siblings, and Partners: A Guide for Professionals (1st ed.). Routledge. https://doi.org/10.4324/9780429507717

Marliyah, L., Dewi, F. I. R., \& Suyasa, T. Y. S. (2004). Keputusan, Persepsi Terhadap Dukungan Orang tua

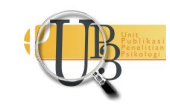


dan Pembuatan Karir Remaja. Jurnal Provitae, 1(1), 59-82.

Maxwell, M., \& Gayle, S. (2013). Counseling adolescent existential issues. Ideas and Research You Can Use: VISTAS, 27, 1-10. https://www.counseling.org/knowledge-center/vistas/by-subject2/vistasfamilies/docs/default-source/vistas/counseling-adolescent-existential-issues

Milburn, T. W., \& Billings, R. S. (1976). Decision-Making Perspectives from Psychology. American Behavioral Scientist, 20(1), 111-126. https://doi.org/10.1177/000276427602000107

Miles, M. B., Huberman, M. (1994). Qualitative Data Analysis Second Edition. SAGE Publications.

Newman, L. F. (1999). Introduction to Qualitative Research Methods: A Guidebook and Resource, Third Edition. The Journal of Nervous \& Mental Disease, 187(9), 587. https://doi.org/10.1097/00005053199909000-00011

Nugrahini, A. K. (2018). Faktor-faktor yang mempengaruhi pemilihan jurusan dan kepuasan dalam menjalani jurusan di perguruan tinggi. [Skripsi, Universitas Sanata Dharma]. https://repository.usd.ac.id/33581/

Osipow, S. H. (1973). A Comparison of The Theories. In Theories of Career Development (pp. 220-223). New York: Appleton-Century-Crofts.

Paloş, R., \& Drobot, L. (2010). The impact of family influence on the career choice of adolescents. Procedia-Social and Behavioral Sciences, 2(2), 3407-3411. https://doi.org/10.1016/j.sbspro.2010.03.524

Parent. (n.d.). Cambridge Dictionary. Retrieved March 18, 2021, from https://dictionary.cambridge.org/dictionary/english/parent

Peilouw, F. J., \& Nursalim, M. (2013). Hubungan antara pengambilan keputusan dengan kematangan emosi dan self-efficacy pada remaja. Jurnal Psikologi Pendidikan Dan Bimbingan, 1 (2) 1-6.

Porfeli, E. J., Lee, B. (2012). Career development during childhood and adolescence. New Directions for Youth Development, 11-22. https://doi.org/https://doi.org/10.1002/yd.20011

Prabowo, W., Yusuf, M., \& Setyowati, R. (2019). Pengambilan Keputusan Menentukan Jurusan Kuliah Ditinjau Dari Student Self Efficacy Dan Persepsi Terhadap Harapan Orang Tua. Jurnal Psikologi Pendidikan Dan Konseling: Jurnal Kajian Psikologi Pendidikan Dan Bimbingan Konseling, 5(1), 4248. https://doi.org/10.26858/jppk.v5i1.7460

Preferensi. (n.d.). KBBI. Retrieved April 24, 2020, from https://kbbi.web.id/preferensi

Rini, Y. S. (2014). Komunikasi Orang tua-Anak dalam Pengambilan Keputusan Pendidikan. Interaksi: Jurnal Ilmu Komunikasi, 3(2), 112-122. https://doi.org/10.14710/interaksi.3.2.112-122

Rogers, M. E., Creed, P. A., \& Praskova, A. (2018). Parent and Adolescent Perceptions of Adolescent Career Development Tasks and Vocational Identity. Journal of Career Development, 45(1), 34-49. https://doi.org/10.1177/0894845316667483

Salim, R. M. A., \& Preston, M. (2019). Parenting Styles Effect on Career Exploration Behavior in

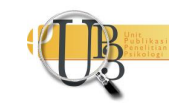


Adolescence: Considering Parents and Adolescent Gender. Humaniora, 10(3), 249-254. https://doi.org/10.21512/humaniora.v10i3.5803

Santrock, J. W. (2019). Adolescence (17th Editi). University of Texas.

Sari, W. (2015). Hubungan Antara Pengetahuan Tentang Karir dan Efikasi Diri dengan Pengambilan Keputusan Karir pada Siswa SMA [Universitas Islam Negeri Sultan Syarif Kasim Riau]. http://repository.uin-suska.ac.id/6438/

Stein, H. T. (n.d.). Adlerian Overview of Birth Order Characteristics. http://www.adlerian.us/birthord.htm

Steinberg, L., \& Silk, J. S. (2002). Parenting Adolescents. In M. H. Bornstein (Ed.), Handbook of Parenting Vol. 1: Children and Parenting (pp. 103-133). Lawrence Erlbaum Associates.

Sulloway, F. J. (1999). Birth Order. In M. A. Runco \& S. R. Pritzker (Eds.), Encyclopedia of Creativity (1st ed., pp. 189-202). Academic Press.

Susilawati, D. (2016). Ortu Indonesia Paling Ingin Anaknya Jadi Dokter. https://www.republika.co.id/berita/gaya-hidup/parenting/16/09/15/odisq3328-ortuindonesia-paling-ingin-anaknya-jadi-dokter

Vignoli, E., Croity-Belz, S., Chapeland, V., de Fillipis, A., \& Garcia, M. (2005). Career exploration in adolescents: The role of anxiety, attachment, and parenting style. Journal of Vocational Behavior, 67(2), 153-168. https://doi.org/10.1016/j.jvb.2004.08.006

Whiteman, S. D., Mchale, S. M., \& Crouter, A. C. (2003). What parents learn from experience: The first child as a first draft? Journal of Marriage and Family, 65(3), 608-621. https://doi.org/10.1111/j.1741-3737.2003.00608.x

Wray-Lake, L., Crouter, A. C., \& McHale, S. M. (2010). Developmental patterns in decision-making autonomy across middle childhood and adolescence: European american parents' perspectives. Child Development, 81(2), 636-651. https://doi.org/10.1111/j.1467-8624.2009.01420.x

Yalom, I. D. (1980). Existential psychotherapy. Basic Books.

Yamamoto, Y., \& Holloway, S. D. (2010). Parental Expectations and Children's Academic Performance in Sociocultural Context. 189-214. https://doi.org/10.1007/s10648-010-9121-z

Yazici, S., \& Yazici, A. (2010). Students' choice of college major and their perceived fairness of the procedure: Evidence from Turkey. Educational Research and Evaluation, 16(4), 371-382. https://doi.org/10.1080/13803611.2010.528196

Zajonc, R. B. (2001). The family dynamics of intellectual development. The American Psychologist, 56(67), 490-496. https://doi.org/10.1037//0003-066x.56.6-7.490

Zamroni, E. (2016). Urgensi Career Decision Making Skills Dalam Penentuan Arah Peminatan Peserta Didik. Jurnal Konseling Gusjigang, 2(2), 140-152. https://doi.org/10.24176/jkg.v2i2.700 